\title{
Abundance of Ixodes ricinus and prevalence of Borrelia burgdorferi s.l. in the nature reserve Siebengebirge, Germany, in comparison to three former studies from 1978 onwards
}

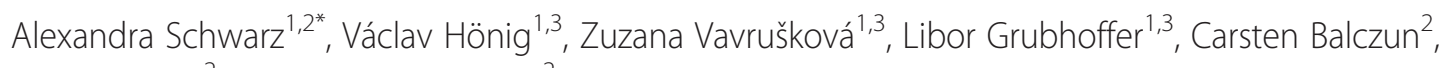
Antje Albring ${ }^{2}$ and Günter A Schaub²

\begin{abstract}
Background: During the last decades, population densities of Ixodes ricinus and prevalences of Borrelia burgdorferi s.l. have increased in different regions in Europe. In the present study, we determined tick abundance and the prevalence of different Borrelia genospecies in ticks from three sites in the Siebengebirge, Germany, which were already examined in the years 1987, 1989, 2001 and 2003. Data from all investigations were compared.

Methods: In 2007 and 2008, host-seeking I. ricinus were collected by monthly blanket dragging at three distinct vegetation sites in the Siebengebirge, a nature reserve and a well visited local recreation area near Bonn, Germany. In both years, 702 ticks were tested for B. burgdorferi s.l. DNA by nested PCR, and 249 tick samples positive for Borrelia were further genotyped by reverse line blotting.

Results: A total of 1046 and 1591 I. ricinus were collected in 2007 and 2008, respectively. In comparison to previous studies at these sites, the densities at all sites increased from 1987/89 and/or from 2003 until 2008. Tick densities and Borrelia prevalences in 2007 and 2008, respectively, were not correlated for all sites and both years. Overall, Borrelia prevalence of all ticks decreased significantly from 2007 (19.5\%) to 2008 (16.5\%), thus reaching the same level as in 2001 two times higher than in 1987/89 (7.6\%). Since 2001, single infections with a Borrelia genospecies predominated in all collections, but the number of multiple infections increased, and in 2007, for the first time, triple Borrelia infections occurred. Prevalences of Borrelia genospecies differed considerably between the three sites, but $B$. garinii or $B$. afzelii were always the most dominant genospecies. B. lusitaniae was detected for the first time in the Siebengebirge, also in co-infections with B. garinii or B. valaisiana.

Conclusions: Over the last two centuries tick densities have changed in the Siebengebirge at sites that remained unchanged by human activity since they belong to a nature reserve. Abiotic and biotic conditions most likely favored the host-seeking activity of I. ricinus and the increase of multiple Borrelia infections in ticks. These changes have led to a potential higher risk of humans and animals to be infected with Lyme borreliosis.
\end{abstract}

Keywords: Ixodes ricinus, Tick density, Borrelia prevalence, Borrelia lusitaniae, Multiple infections, Siebengebirge

\footnotetext{
* Correspondence: alexandraschwarz@arcor.de

${ }^{1}$ Institute of Parasitology, Biology Centre, Academy of Sciences of Czech Republic, České Budĕjovice, Czech Republic

${ }^{2}$ Group Zoology/Parasitology, Ruhr-Universität Bochum, Bochum, Germany

Full list of author information is available at the end of the article
} 


\section{Background}

Ticks are obligate hematophagous ectoparasites and important vectors of infectious diseases transmitting parasites of livestock and humans, e.g. the etiologic agents of babesiosis, theileriosis or anaplasmosis and of human tick-borne encephalitis and Lyme disease [1,2]. The sheep tick Ixodes ricinus is the most common tick species and principal vector for various infectious diseases in Europe and some regions of Asia and North Africa [3]. The distribution and abundance of $I$. ricinus depends on various abiotic and biotic factors such as the microclimate, habitat (vegetation) and host cenosis [4]. The host-seeking activity of $\mathrm{I}$. ricinus is favored by air temperatures between $7{ }^{\circ} \mathrm{C}$ and $24^{\circ} \mathrm{C}$ and relative humidities of $45-100 \%$ due to the risk of desiccation [5,6]. Ecosystems that have a strong buffering capacity, for example, for humidity, such as mixed deciduous and coniferous forests with well-developed leaf and shrub layers are preferred tick habitats $[7,8]$. However, also forest biotopes differ in the abundances of $I$. ricinus, presumably correlated to the water content of the soil $[7,8]$.

Since the development and survival of ticks strongly depends on climatic conditions, the distribution and abundance of ticks might also be influenced by global warming. In Sweden, the distribution of I. ricinus extended towards the north, and this was suggested to be caused by increased air temperatures which favored the survival, activity and development of ticks [4]. Similarly, in the Czech Republic I. ricinus spread towards higher altitudes, from $700 \mathrm{~m}$ to $1100 \mathrm{~m}$ above the sea level within the last 20 years [9].

In addition to climatic factors, the host cenosis also affects the distribution and abundance pattern of ixodid ticks. I. ricinus is an euryphage species that has a broad host spectrum and thus feeds on more than 300 vertebrate species [10]. It predominantly infests small rodents (mice), passerine birds and larger mammals such as hedgehogs, hares, squirrels, wild boar and roe deer [11]. Increased population densities of these hosts induce an increase in the densities of ticks (summarized by [8]). In addition, also the anthropogenic impact on habitat changes the temporal and spatial pattern of tick populations [12].

An increase in the abundance of Ixodes can increase the transmission risk of diseases, e.g. of the spirochete bacterium Borrelia burgdorferi sensu lato, the etiologic agents of Lyme disease which is endemic in Europe [13]. Prevalences of B. burgdorferi s.l. in I. ricinus range up to $11 \%$, $43 \%$ and $58 \%$ in larvae, nymphs and adults, respectively [14]. During the last decades, Borrelia prevalences have increased in different regions in Europe, such as in Denmark and Germany $[15,16]$. Infection prevalences differ between different regions in Europe because the transmission of Borrelia depends on a complex zoonotic cycle between their reservoir hosts and their tick vectors. More than 50 avian and mammalian hosts are reservoir hosts for B. burgdorferi s.l. in Europe [17].

Different genospecies have been identified in the $B$. burgdorferi s.l. complex. In Europe, seven genospecies are prevalent, B. burgdorferi sensu stricto, B. afzelii, B. garinii, B. valaisiana, B. bissettii, B. spielmanii, $B$. lusitaniae $[18,19]$, and B. bavariensis, a recently classified genospecies [20] that was previously described as the rodent-associated $B$ garinii OspA serotype 4 [21]. Usually B. burgdorferi s.s., B. afzelii and B. garinii (including $B$. bavariensis) are present in tissues of Lyme disease patients [22,23]. Spirochetes of B. valaisiana were isolated from a few patients who showed erythema migrans or acrodermatitis chronica atrophicans manifestations and an old man who showed strong clinical evidence of neuroborreliosis [23,24]. B. bissettii was detected in tissues from a few patients suffering from Lyme borreliosis in Slovenia and in the Czech Republic $[25,26]$. B. spielmanii was present in the skin of a few patients with erythema migrans [27]. Only once, $B$. lusitaniae was identified in a patient, but he showed symptoms that are untypical for the clinical manifestations of Lyme disease [28]. In I. ricinus from Slovakia, Latvia, Germany, Portugal and the United Kingdom, the most prevalent Borrelia genospecies were B. afzelii, B. garinii (including $B$. bavariensis) and $B$. valaisiana with overall prevalences of $39.3 \%, 21.2 \%$ and $12.8 \%$, respectively [29].

Prevalence and the distribution of Borrelia genospecies strongly depend on the local host cenosis due to the host/s reservoir competence [30]. B. afzelii is mainly associated with rodents and $B$. garinii and B. valaisiana with birds [31]. Both, rodents and birds are competent reservoir hosts of Borrelia burgdorferi s.s. [32]. Rodents do also serve as reservoir hosts of $B$. bissettii and $B$. bavariensis [21,33] and the garden dormouse seems to be the main reservoir host of $B$. spielmanii in Central Europe [34]. B. lusitaniae is associated with birds and lizards $[35,36]$.

In the present investigation, we determined the abundance of $I$. ricinus and the prevalence of Borrelia and of the different genospecies in ticks in the Siebengebirge, a nature reserve and well visited local recreation area near Bonn, Germany. In 2007 and 2008, ticks were collected at three sites that represented different plant communities and possessed different population densities of $I$. ricinus. These sites have been already examined in previous investigations in the years 1987, 1989, 2001 and 2003 [8,15,37]. Thus, abundance and prevalence were compared with previous investigations.

\section{Methods}

Study area and tick collections of all studies since 1978

In 1987 and 1989, 2001, 2003, 2007 and 2008 hostseeking ticks (nymphs and adults) were collected in the 
nature reserve Siebengebirge, a forested and hilly region located south-east of Bonn [8]. As presented in Table 1, ticks were collected throughout the seasonal tick activity period in each study year in the Siebengebirge. In all years, exactly at the same sites in three plant communities, the Fraxino-Aceretum pseudoplatani, the LuzuloFagetum milietosum (Athyrium filix-femina variant) and the Galio-Fagetum typicum (considered as MelicoFagetum typicum by $[15,37,38]$ ) were chosen for the tick collections $[8,15,37,38]$. A detailed description of the examined plant communities including a map of the exact study sites was previously published in Schwarz et al. [8]. Briefly, study site 1 (N50³9'37.1",E $7^{\circ} 14$ '55.4', 298m) in the Galio-Fagetum typicum (considered as Melico-Fagetum typicum by [15,37] and study field 2 by Schwarz et al. [8]) possessed a highly developed herb layer and well-developed shrub layer (dominant plant species, e.g. Melica uniflora) and a dry to wet soil water capacity [8]. Study site 2 (N50³9'53.2", E7 $13^{\prime} 05.8^{\prime \prime}, 130 \mathrm{~m}$, site 3 by [8]) in the Fraxino-Aceretum pseudoplatani was a dry to fresh vegetation type with a poorly developed herb and shrub layer (dominant plant species, e.g. Dentaria bulbifera). The soil water capacity was moderate. The third study site (N50³9'51.5", E7²13'19.2", 123m, site 4 by [8]) located in the Luzulo-Fagetum milietosum was the richest plant community in species and plant densities (dominant plant species, e.g. Athyrium filix-femina) and it had a high soil water capacity. In our previous study in 2003, medium, low and high numbers of ticks were characteristic for the Galio-Fagetum typicum, the
Fraxino-Aceretum pseudoplatani and the LuzuloFagetum milietosum, respectively [8].

In all Siebengebirge/s studies, ticks were collected monthly by repeated blanket dragging $[8,37,38]$, with the exception of the study in 2001 when weekly tick collections were carried out [15] (Table 1). In all studies, a cotton flannel was used for blanket dragging, and the sites were repeatedly re-flagged until no more ticks were collected. According to Hubálek et al. [6], tick collections in 2003, 2007 and 2008 were carried out when air temperatures were between $7{ }^{\circ} \mathrm{C}$ and $24^{\circ} \mathrm{C}$ and a relative humidity between $45 \%$ and $100 \%$ without rain and no strong winds occurred. The effective measured temperature and relative humidity ranges at the collection sites were listed for the three years in Table 1 . In the years 1978, 1989 and 2001 ticks were collected when at least $16^{\circ} \mathrm{C}$ and $80 \%$ relative humidity was reached without rain and no strong winds $[15,37,38]$. All collected ticks were preserved in $70 \%$ ethanol and identified to species level in the laboratory [39].

\section{DNA extraction}

In a chronological arrangement of the methodologies, in 2008 all adults and up to about 60 nymphs/month/site (in total 61 adults and 641 nymphs) were homogenized each in $200 \mu \mathrm{l} 20 \%$ Chelex 100 resin solution (Bio-Rad) using the TissueLyser II (Qiagen) and stainless steel beads $(5 \mathrm{~mm})[40,41]$. For total DNA extraction, $120 \mu \mathrm{l}$ of each homogenate were incubated at $56^{\circ} \mathrm{C}$ overnight, vortexed and incubated for $10 \mathrm{~min}$ at $96^{\circ} \mathrm{C}$. After

Table 1 Overview of the methodological differences in the Ixodes ricinus studies in the Siebengebirge in 1987, 1989, 2001, 2003, 2007 and 2008

\begin{tabular}{|c|c|c|c|c|c|}
\hline Methods & 1987/89* & 2001 & 2003 & 2007 & 2008 \\
\hline Months $^{1}$ & Apr-Oct & May, Aug-Oct & May-Nov & May-Nov & May-Nov \\
\hline Frequency & monthly & weekly & weekly & monthly & monthly \\
\hline Size & $100 m^{2}$ & $100 m^{2}$ & $225 \mathrm{~m}^{2}$ & $100 m^{2}$ & $100 m^{2}$ \\
\hline Air temp. ${ }^{2}$ & $\geq 16^{\circ} \mathrm{C}$ & $\geq 16^{\circ} \mathrm{C}$ & $8^{\circ} \mathrm{C}-25^{\circ} \mathrm{C}$ & $15^{\circ} \mathrm{C}-25^{\circ} \mathrm{C}$ & $15^{\circ} \mathrm{C}-23^{\circ} \mathrm{C}$ \\
\hline Humidity $^{2}$ & $\geq 80 \%$ & $\geq 80 \%$ & $57 \%-74 \%$ & $45 \%-85 \%$ & $52 \%-85 \%$ \\
\hline DNA extraction & $\mathrm{n} / \mathrm{a}^{3}$ & Ammonia solution & $\mathrm{n} / \mathrm{a}$ & Ammonia solution & Chelex 100 resin solution \\
\hline \multirow[t]{4}{*}{ Borrelia detection } & $\mathrm{IFA}^{+}$ & Simple, modified PCR [45] & $\mathrm{n} / \mathrm{a}$ & Nested PCR [44] & Nested PCR [44] \\
\hline & & Nested PCR [44] & & & \\
\hline & & Modified PCR [46] & & & \\
\hline & & IFA $[15,38]$ & & & \\
\hline Borrelia genotyping & $\mathrm{n} / \mathrm{a}$ & Reverse line blotting ${ }^{4}$ [44] & $\mathrm{n} / \mathrm{a}$ & Reverse line blotting ${ }^{5}[44,47]$ & Reverse line blotting ${ }^{5}[44,47]$ \\
\hline
\end{tabular}

*The years 1987 and 1989 are listed together because the same methods were used in both study years for the study of $I$. ricinus abundances and Borrelia prevalences.

${ }^{1}$ Tick collections were carried out in the respective months (Apr $=$ April, Aug $=$ August, Oct $=$ October, Nov $=$ November $)$.

${ }^{2}$ Air temperatures and relative humidities were measured $5 \mathrm{~cm}$ above the ground at the study sites in all years.

${ }^{3} \mathrm{n} / \mathrm{a}=$ not applicable.

${ }^{4}$ B. burgdorferi s.l., B. burgdorferi s.S., B. garinii, B. afzelii and B. valaisiana were identified by reverse line blotting according to Rijpkema et al. [44].

${ }^{5}$ B. burgdorferi s.l., B. burgdorferi s.s., B. garinii and B. afzelii were identified by reverse line blotting according to Rijpkema et al. [44] and DNA probes for B. garinii,

B. valaisiana, B. lusitaniae, B. spielmanii and B. bissettii were designed according to Gern et al. [47].

${ }^{+}$IFA $=$Immunofluorescence assay. 
centrifugation at $15,000 \mathrm{~g}$ for $3 \mathrm{~min}$, the supernatant was used directly for PCR.

In 2007, all adults and up to about 90 nymphs/month/ site (in total 50 adults and 652 nymphs) were pestled each in $100 \mu \mathrm{l} 1.25 \%$ ammonia [42]. The tick homogenates were boiled at $100^{\circ} \mathrm{C}$ for $20 \mathrm{~min}$, cooled down briefly, centrifuged at $16,000 \mathrm{~g}$ for $5 \mathrm{~min}$ and the supernatants boiled again to evaporate the ammonia until $30 \mu \mathrm{l}$ of DNA solution was left.

In 2001, Kampen et al. [15] randomly selected 366 nymphs and 179 adults in 2001 for Borrelia examination. Similar to our study in 2007, the DNA of these ticks was extracted by ammonia (Table 1 ).

The following B. burgdorferi s.l. genospecies served as positive controls in PCR and/or reverse line blottings: B. burgdorferi sensu stricto N40, B31 and CB53, B. garinii PSth, B. afzelii VS461, B. valaisiana VS116 and B. lusitaniae PotiB3. The strains N40 and PSth were provided by the Baden-Wuerttemberg State Health Office, Stuttgart, Germany, B31 by J. F. Anderson (Connecticut Experiment Station, New Haven, USA), CB53 by J. Kopecký (Institute of Parasitology, ASCR, České Budějovice, Czech Republic) and the strains VS461, VS116 and PotiB3 by Ian Livey (Baxter Innovations, Orth an der Donau, Austria). All bacteria were cultured in BSK-H medium (Sigma-Aldrich) at $34^{\circ} \mathrm{C}$ as described previously [43].

Total DNA of the B. burgdorferi s.s. strain N40 and B. garinii PSth was isolated using Chelex 100 (Bio-Rad) [40]. Briefly, $100 \mu \mathrm{l}$ of each Borrelia culture was centrifuged and the pellet resuspended in $40 \mu \mathrm{l}$ of a $20 \%$ Chelex 100 suspension. The suspensions were incubated at $56^{\circ} \mathrm{C}$ for $30 \mathrm{~min}$ and, after thoroughly mixing, boiled for 10 min. Chelex 100 was removed by a final centrifugation step and the supernatant stored at $-20^{\circ} \mathrm{C}$. DNA of the $B$. burgdorferi s.s. strains B31 and CB53, B. afzelii VS461, B. valaisiana VS116 and B. lusitaniae PotiB3 were prepared using the DNeasy Blood and Tissue Kit (Qiagen) according to the manufacturer/s instructions.

\section{Detection of $B$. burgdorferi s.l.}

In 2008 and 2007, ticks were tested for Borrelia DNA by nested PCR according to Rijpkema et al. [44]. The first PCR mix contained $5 \mu$ total DNA and final concentrations of $200 \mathrm{nM} \mathrm{B.} \mathrm{burgdorferi} \mathrm{s.l.} \mathrm{specific} \mathrm{primers} \mathrm{tar-}$ geting the 5S-23S rDNA intergenic spacer region (23SN1 and 23SC1; [44]), $100 \mu \mathrm{M}$ dNTPs, $1.5 \mathrm{mM}$ $\mathrm{MgCl}_{2}$ and $1.25 \mathrm{U}$ GoTaq Flexi DNA Polymerase (Promega). The following DNA amplification step using 35 cycles was set up: $94^{\circ} \mathrm{C}$ for $30 \mathrm{sec}, 53^{\circ} \mathrm{C}$ for $30 \mathrm{sec}$ and $72^{\circ} \mathrm{C}$ for $1 \mathrm{~min}$. For the second PCR, $5 \mu \mathrm{l}$ of the first PCR product using the same PCR mix and the specific primers 23SN1 and $5 \mathrm{SCB}$ without biotin label of the 5S-23S rDNA intergenic spacer region were used [44].
The same thermal cycling conditions of the first PCR were set up for the second PCR but using a primer annealing temperature of $55^{\circ} \mathrm{C}$. Positive and negative controls were always included, and nested PCR products were screened for B. burgdorferi s.l. DNA by agarose gel electrophoresis.

In 2001 [15], Borrelia infection in ticks were analyzed by simple and nested PCR and immunofluorescence assay (IFA) according to Liebisch et al. [45] (with modifications), Rijpkema et al. [44] and Kurtenbach et al. [38]/Kampen et al. [15], respectively. A third, modified PCR protocol originally performed by Schwartz et al. [46] was additionally applied in 2001 if contradictory results between the simple and nested PCR approaches occurred.

In 1987, Kurtenbach et al. [38] examined 1189 nymphal and adult $I$. ricinus and 1050 nymphs and adults in 1989 for Borrelia infection. Borrelia prevalences were calculated without specification of the respective year; only prevalences of 1987/89 were published. The same IFA protocol as used by Kampen et al. [15] in 2001 was carried out for the tick examinations in $1987 / 89$ [38].

\section{Genotyping of Borrelia species}

A total of 249 tick samples positive for B. burgdorferi s.l. in 2007 and 2008 were further identified to the genospecies level [47]. Briefly, B. burgdorferi s.l. DNA was amplified by PCR using the 5/-biotinylated Borrelia specific B-5SBor primer and the 23SBor primer [48]. A touchdown PCR with an annealing temperature starting from $60^{\circ} \mathrm{C}$ to $52^{\circ} \mathrm{C}\left(1^{\circ} \mathrm{C}\right.$ decrease per cycle) was set up to minimize amplification of non-specific DNA products. After the final annealing temperature was reached a further amplification step of 40 cycles using $52^{\circ} \mathrm{C}$ was carried out [49]. Amplification products were hybridized to 14 Borrelia specific oligonucleotide probes detecting the following genospecies [47]: B. burgdorferi s.l. (SL probe), B. burgdorferi s.s. (SS probe), B. garinii (GA, GANE and GANE1 probe), B. afzelii (AF probe), B. valaisiana (VSNE probe), B. lusitaniae (LusiNE, LusiNE1 and LusiNE2 probe), B. spielmanii (SpiNE2 and SpiNE3 probe) and B. bissettii (BisNE1 and BisNE2 probe). $B$. burgdorferi s.l., B. burgdorferi s.s., B. garinii and B. afzelii probes were designed according to Rijpkema et al. [44]. All other probes (including probes GANE and GANE1) were used according to Gern et al. [47]. Hybridized products were visualized by chemiluminescence using the ECL Detection Reagent and Hyperfilm ECL (GE Healthcare). Negative controls were included, and Borrelia DNA of the different genospecies served as positive controls. Additionally, Borrelia PCR products that hybridized with the probes GA, GANE1 and LusiNE1 were sequenced using OspA primers in order to distinguish 
between $B$. garinii and $B$. bavariensis genotypes as described previously $[47,50]$.

Additionally, Borrelia samples from 2001 were genotyped by Kampen et al. [15] also using reverse line blotting. Similar to the studies in 2007 and 2008, probes for Borrelia identification targeted the 5S-23S rDNA spacer region. Probes were designed for the detection of $B$. burgdorferi s.l., B. burgdorferi s.s., B. garinii, B. afzelii and B. valaisiana according to Rijpkema et al. [44]. $B$. lusitaniae, B. spielmanii and B. bissettii identifications were not carried out in 2001.

\section{Data analysis}

Tick densities and Borrelia prevalences were compared between the different studies in the Siebengebirge from $1987 / 89$ to 2008 . For tick density comparisons, only the months May to September were compared from each study year and the densities were calculated for $100 \mathrm{~m}^{2}$ of study site. Therefore, the average monthly tick abundances from 2003 were recalculated from $225 \mathrm{~m}^{2}$ to $100 \mathrm{~m}^{2}$.

For the comparison of Borrelia prevalences throughout the different study years, IFA data from 1987/89 and 2001 were compared and nested PCR Borrelia data from 2001 with the results from 2007 and 2008 because in those years the same experimental protocols were used. In 2001, the same ticks were examined by IFA and nested PCR by Kampen et al. [15].

Statistical analysis of data was performed using Prism 4 (GraphPad Software). Differences in tick abundances, infection prevalences with Borrelia and B. burgdorferi s.l. genospecies between the three study sites and study years were analyzed by the chi square test or MannWhitney U test. Only Borrelia prevalences derived from more than 20 ticks were statistically compared. Climate parameters between different years of the last two centuries were compared by a one - way analysis of variance (One -Way ANOVA) with a pairwise multiple comparison procedure (Tukey test), the Kruskal-Wallis test or the Mann-Whitney U test. Correlations of tick densities with Borrelia prevalences were tested using the Spearman's Rho rank correlation test. P-values of 0.05 or less were considered statistically significant for all tests.

\section{Results}

\section{Abundances of $I$. ricinus in 2007 and 2008}

Exclusively $I$. ricinus ticks were captured by blanket dragging. In 2007, a total of 1046 host-seeking ticks (50 adults, 996 nymphs) were collected (Table 2). In the Fraxino-Aceretum pseudoplatani, the plant community representing a low abundance biotope, the number of host seeking ticks decreased from May to July and increased up to September (Figure 1). In the other two plant communities, the Luzulo-Fagetum milietosum and the Galio-Fagetum typicum, that possessed higher numbers of ticks, the densities increased from May to June, decreased until August and increased slightly or remained at the same level in September (Figure 1). In 2008, a total of 1591 host-seeking I. ricinus (61 adults, 1530 nymphs) were collected at the three sites (Table 2). In the Fraxino-Aceretum pseudoplatani plant community more ticks were collected than one year before, and the monthly abundance graph showed a peak in June and no ticks in September (Figure 1). This was also evident for the site with the highest abundances, the GalioFagetum typicum, but at a higher abundance level, and a few ticks were collected in September (Figure 1). In the Luzulo-Fagetum milietosum, densities were similar in

Table 2 Number of Ixodes ricinus and infection rates with B. burgdorferi s.l. at three plant communities in the Siebengebirge in 2007 and 2008

\begin{tabular}{|c|c|c|c|c|c|c|c|c|c|c|c|c|c|c|c|}
\hline \multirow{4}{*}{ Plant community } & \multirow{4}{*}{$\begin{array}{l}\text { Tick } \\
\text { stage* }\end{array}$} & \multicolumn{7}{|c|}{2007} & \multicolumn{7}{|c|}{2008} \\
\hline & & \multirow[t]{3}{*}{$\begin{array}{l}\text { Total no. } \\
\text { of ticks }\end{array}$} & \multirow{2}{*}{\multicolumn{5}{|c|}{$\begin{array}{l}\text { No. of infected ticks/ } \\
\text { no. of examined ticks } \\
\text { Month }^{\#}\end{array}$}} & \multirow{3}{*}{$\begin{array}{c}\text { Total } \\
\text { infection } \\
\text { rate }(\%)\end{array}$} & \multirow[t]{3}{*}{$\begin{array}{l}\text { Total no. } \\
\text { of ticks }\end{array}$} & \multirow{2}{*}{\multicolumn{5}{|c|}{$\begin{array}{c}\begin{array}{c}\text { No. of infected ticks/ } \\
\text { No. of examined ticks }\end{array} \\
\text { Month }^{\#}\end{array}$}} & \multirow{3}{*}{$\begin{array}{c}\text { Total } \\
\text { infection } \\
\text { rate (\%) }\end{array}$} \\
\hline & & & & & & & & & & & & & & & \\
\hline & & & $M$ & $\mathrm{JN}$ & $J$ & $A$ & $\mathrm{~s}$ & & & $M$ & $\mathrm{JN}$ & $J$ & $A$ & $\mathrm{~S}$ & \\
\hline \multirow{2}{*}{$\begin{array}{l}\text { Fraxino-Aceretum } \\
\text { pseudoplatani }\end{array}$} & $A$ & 6 & $0 / 3$ & $0 / 1$ & $0 / 0$ & $0 / 2$ & $0 / 0$ & 0 & 23 & $4 / 13$ & $0 / 2$ & $1 / 7$ & $0 / 1$ & $0 / 0$ & 21.7 \\
\hline & $\mathrm{N}$ & 100 & $12 / 46$ & $1 / 13$ & $0 / 1$ & $0 / 5$ & $7 / 35$ & 20.0 & 340 & $5 / 47$ & $11 / 58$ & $8 / 46$ & $4 / 32$ & $0 / 0$ & 15.3 \\
\hline \multirow{2}{*}{$\begin{array}{l}\text { Luzulo-Fagetum } \\
\text { milietosum }\end{array}$} & A & 18 & $1 / 4$ & $0 / 12$ & $0 / 2$ & $0 / 0$ & $0 / 0$ & 5.6 & 15 & $0 / 8$ & $0 / 0$ & $0 / 6$ & $1 / 1$ & $0 / 0$ & 6.7 \\
\hline & $\mathrm{N}$ & 288 & $14 / 91$ & $33 / 88$ & $2 / 35$ & $2 / 12$ & $0 / 10$ & 21.6 & 482 & $5 / 52$ & $27 / 61$ & $4 / 54$ & $18 / 55$ & $4 / 8$ & 25.2 \\
\hline \multirow{2}{*}{$\begin{array}{l}\text { Galio-Fagetum } \\
\text { typicum }\end{array}$} & A & 26 & 0/9 & $1 / 6$ & $1 / 6$ & $0 / 2$ & $2 / 3$ & 15.4 & 23 & $1 / 8$ & $2 / 9$ & $0 / 1$ & $1 / 5$ & $0 / 0$ & 17.4 \\
\hline & $\mathrm{N}$ & 608 & $14 / 91$ & $18 / 94$ & $12 / 86$ & $3 / 16$ & $14 / 29$ & 19.3 & 708 & $6 / 53$ & $4 / 52$ & $3 / 59$ & $6 / 55$ & $1 / 9$ & 8.8 \\
\hline \multirow[t]{3}{*}{ Total } & A & 50 & & & $5 / 50$ & & & 10.0 & 61 & & & $10 / 61$ & & & 16.4 \\
\hline & $\mathrm{N}$ & 996 & & & $132 / 652$ & & & 20.2 & 1530 & & & 106/641 & & & 16.5 \\
\hline & All & 1046 & & & 137/702 & & & 19.5 & 1591 & & & 1 16/702 & & & 16.5 \\
\hline
\end{tabular}

* The total number of collected adult $(\mathrm{A})$ and nymphal $(\mathrm{N})$ of $l$. ricinus at the three study sites are separately presented.

\# Ticks were collected in May (M), June (JN), July (JL), August (A) and September (S) of 2007 and 2008 at the three study sites of the Siebengebirge. 
Figure 1 Monthly abundances of $I$. ricinus and Borrelia burgdorferi s.l. prevalences at three study sites in the Siebengebirge in 2007 and 2008. From May to September 2007 and 2008, host-seeking I. ricinus were collected by blanket dragging at three plant communities (Galio-Fagetum typicum, FraxinoAceretum pseudoplatani and Luzulo-Fagetum milietosum) in the nature reserve Siebengebirge, and the ticks were examined for Borrelia infection. The monthly abundances of ticks (columns) and Borrelia burgdorferi s.l. prevalences (line diagram) in 2007 (black squares) and 2008 (white squares) at the three study sites are presented in the figure.

May, June and July and decreased until September (Figure 1).

Summarizing the numbers of ticks of all sites per year, population densities increased significantly from 2007 to $2008\left(x^{2}=179.9, \mathrm{df}=4, \mathrm{p}<0.0001\right)$. Highest densities of 339 and 289 ticks $/ 100 \mathrm{~m}^{2}$ were found in the GalioFagetum typicum in June 2007 and 2008, respectively (Figure 1), but densities did not differ statistically significantly in direct comparison of the numbers in the GalioFagetum typicum and the Luzulo-Fagetum milietosum in $2007\left(x^{2}=7.409, d f=4, p>0.1\right)$. Excluding the lower numbers of collected ticks at all sites in September, densities increased from 2007 to 2008 up to 4.5 -fold. This was caused by the enormous increase in the numbers of nymphal ticks since numbers of collected adults changed only slightly between the two years (Table 2).

\section{B. burgdorferi s.l. infection rates in 2007 and 2008}

In 2007, 137 of 702 examined ticks (19.5\%; 5 adults and 132 nymphs of 50 adults and 652 nymphs) were infected with B. burgdorferi s.l. (Table 2). In 2008, 116 of 702 ticks (10 adults and 106 nymphs of 61 adults and 641 nymphs) were infected, resulting in a prevalence of $16.5 \%$. In 2007 , at all collection sites, infection rates of nymphal ticks were significantly higher than that of adults $\left(\chi^{2}=13.62, \mathrm{df}=2, \mathrm{p}<0.01\right.$, Table 2). However, in 2008 significantly more adults than nymphs were infected in the Galio-Fagetum typicum and FraxinoAceretum pseudoplatani sites $\left(x^{2}=13.44, \mathrm{df}=2, \mathrm{p}<0.01\right)$, but the overall Borrelia prevalence in 2008 did not differ between nymphs and adults (Table 2).

In the Galio-Fagetum typicum, overall Borrelia prevalences were lower in 2007 than in 2008 (Mann-Whitney $\mathrm{U}$ test, $\mathrm{p}=0.0286$ ) (Figure 1 ). At the other two sites, the infection rates did not differ statistically significantly between both years. In addition, Borrelia prevalences and tick densities were not correlated for all sites and both years (Spearman's rank correlation, $\mathrm{r}=-0.3163, \mathrm{p}>0.05$ ). In 2007 and $2008,0-33$ and $0-27$ infected ticks $/ 100 \mathrm{~m}^{2}$ per month, respectively, were found in all plant communities. Excluding months representing prevalences based on $<20$ ticks, no strong differences in the prevalence between the different months were evident in the Fraxino- 
Aceretum pseudoplatani and Galio-Fagetum typicum for both years; only the latter showed an increase of the infection rate up to $50 \%$ in September 2007. In the Luzulo-Fagetum milietosum, in both years prevalences of Borrelia in June were about two and six times higher than in May and July.

\section{Distribution of B. burgdorferi s.l. genospecies in 2007 and 2008}

The ticks of the Siebengebirge were infected with five genospecies, B. garinii, B. afzelii, B. valaisiana, $B$. burgdorferi s.s. and $B$. lusitaniae. B. spielmanii, $B$. bissettii and $B$. bavariensis could not be detected at any site in both years. In 2007, the two most prominent genospecies in single and multiple Borrelia infections were B. garinii (58.6\%) and B. afzelii (56.4\%). Overall infection rates of the other genospecies were: $9.0 \%$ of $B$. valaisiana, $5.3 \%$ of $B$. burgdorferi s.s. and $11.3 \%$ of $B$. lusitaniae. The highest rates of B. garinii, $78.4 \%$, occurred in the Luzulo-Fagetum milietosum and of B. afzelii, $87.1 \%$, in the Galio-Fagetum typicum (Figure 2). B. lusitaniae appeared only at two sites and only in spring (apart from one infected tick in the Fraxino-Aceretum pseudoplatani in September) with a prevalence of $27.5 \%$ in ticks from the Luzulo-Fagetum milietosum, and B. burgdorferi s.s. only occurred in the Galio-Fagetum typicum (Figure 2).

In 2008, the genospecies composition differed significantly from that of $2007\left(x^{2}=41.16, d f=4, p<0.0001\right)$, but Borrelia infected $I$. ricinus also mainly contained $B$. garinii (overall infection prevalence at all sites including multiple infections: 53.4\%). As in 2007, the highest prevalence with B. garinii occurred in the LuzuloFagetum milietosum (Figure 2). However, the overall infection prevalences of the other genospecies differed, with $26.7 \%$ for B. afzelii, $19.8 \%$ for B. valaisiana and $30.2 \%$ for B. burgdorferi s.s. At two sites B. afzelii prevalences were about 50\% lower than in 2007, whereas $B$. valaisiana prevalences were higher in two plant communities (Figure 2). The strongest changes were evident for B. burgdorferi s.s. and B. lusitaniae. B. burgdorferi s.s. rates increased remarkably at two sites and this genospecies was detected for the first time in 2008 at all three sites. B. lusitaniae was not identified in 2008 in any plant community (Figure 2).

A comparison of the distribution of the different genospecies in nymphs and adults cannot be performed, since infections of only 15 adult ticks were identified; nine ticks with single infections covered one of the five genospecies (Table 3). Summarizing data of nymphs and adults for a comparison of single and multiple infections revealed the predominance of single Borrelia infections with $B$. afzelii or B. garinii in both years (Table 3). In 2007 , both genospecies also predominated in six combinations of double infections (Table 3 ). The frequency of

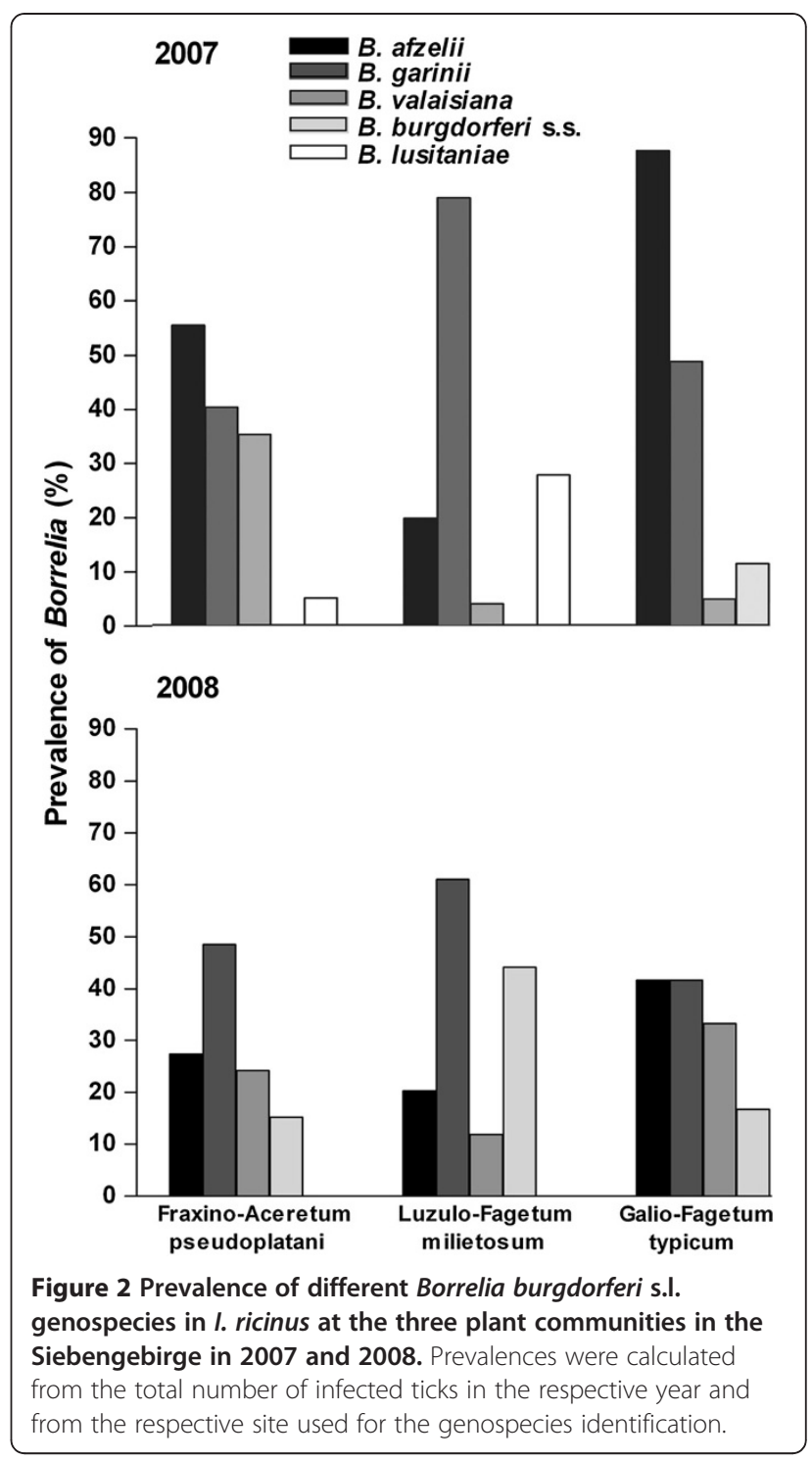

a specific Borrelia genospecies detected either as a single or a co-infection with other species did not differ significantly $\left(x^{2}=0.05, \mathrm{df}=3, \mathrm{p}>0.05\right)$, e.g. 35 ticks were singly infected with $B$. afzelii and 40 ticks with this genospecies as well as at least one other Borrelia species in 2007. A high rate of multiple infections of $32.3 \%$ is only evident for the B. afzelii/B. garinii double infection in the Galio-Fagetum typicum. In this biotope, also the only type of a triple infection with $B$. afzelii, $B$. garinii and $B$. burgdorferi s.s. occurred. Additionally, $B$. burgdorferi s.s. was only detected in double and these triple infections of $I$. ricinus, not as a single infection in 2007 (Table 3).

In 2008, significantly more single than multiple infections with $B$. garinii predominated at three study sites $\left(x^{2}=9.8, d f=3, p<0.05\right)$ (Table 3$)$. For B. garinii single infections ranged between $25.0 \%$ and $39.4 \%$ and for the 
Table 3 Total number (No.) and percentage (\%) of single and multiple infections of ticks with Borrelia afzelii (AF), B. garinii (GA), B. valaisiana (VA), B. burgdorferi s.s. (SS) and B. Iusitaniae (LU) at the three collection sites

\begin{tabular}{|c|c|c|c|c|c|c|c|c|c|c|c|c|}
\hline \multirow{3}{*}{$\begin{array}{l}\text { Plant community } \\
\text { Geno- } \\
\text { species }\end{array}$} & \multicolumn{4}{|c|}{ Fraxino-Aceretum pseudoplatani } & \multicolumn{4}{|c|}{ Luzulo-Fagetum milieotosum } & \multicolumn{4}{|c|}{ Galio-Fagetum typicum } \\
\hline & \multicolumn{2}{|c|}{2007} & \multicolumn{2}{|c|}{2008} & \multicolumn{2}{|c|}{2007} & \multicolumn{2}{|c|}{2008} & \multicolumn{2}{|c|}{2007} & \multicolumn{2}{|c|}{2008} \\
\hline & No. $^{a}$ & $\%^{\mathbf{b}}$ & No. $^{a}$ & $\%^{\mathbf{b}}$ & No. $^{a}$ & $\%^{\mathbf{b}}$ & No. $^{a}$ & $\%^{\mathrm{b}}$ & No. $^{a}$ & $\%^{\mathbf{b}}$ & No. $^{a}$ & $\%^{\mathrm{b}}$ \\
\hline$\overline{\mathrm{AF}}$ & 6 & 30.0 & $5^{1}$ & 15.2 & 3 & 5.9 & 2 & 3.4 & 26 & 41.9 & 4 & 16.7 \\
\hline GA & 4 & 20.0 & $13^{3}$ & 39.4 & 25 & 49.0 & 23 & 39.0 & 6 & 9.7 & $6^{1}$ & 25.0 \\
\hline VA & 3 & 15.0 & 6 & 18.2 & 1 & 2.0 & 4 & 6.8 & 1 & 1.6 & $5^{2}$ & 20.8 \\
\hline SS & 0 & 0.0 & 4 & 12.1 & 0 & 0.0 & $12^{1}$ & 20.3 & 0 & 0.0 & 2 & 8.3 \\
\hline LU & 0 & 0.0 & 0 & 0.0 & $7^{1}$ & 13.7 & 0 & 0.0 & 0 & 0.0 & 0 & 0.0 \\
\hline $\mathrm{AF} / \mathrm{GA}$ & 3 & 15.0 & $2^{1}$ & 6.1 & 7 & 13.7 & 1 & 1.7 & $20^{3}$ & 32.3 & 2 & 8.3 \\
\hline AF/NA & 2 & 10.0 & 1 & 3.0 & 0 & 0.0 & 1 & 1.7 & 1 & 1.6 & 2 & 8.3 \\
\hline AF/SS & 0 & 0.0 & 1 & 3.0 & 0 & 0.0 & 4 & 6.8 & $4^{1}$ & 6.5 & 1 & 4.2 \\
\hline GANA & 1 & 5.0 & 1 & 3.0 & 1 & 2.0 & 2 & 3.4 & 1 & 1.6 & 0 & 0.0 \\
\hline GA/SS & 0 & 0.0 & 0 & 0.0 & 0 & 0.0 & 6 & 10.2 & 0 & 0.0 & $1^{1}$ & 4.2 \\
\hline GA/LU & 0 & 0.0 & 0 & 0.0 & 7 & 13.7 & 0 & 0.0 & 0 & 0.0 & 0 & 0.0 \\
\hline VA/LU & 1 & 5.0 & 0 & 0.0 & 0 & 0.0 & 0 & 0.0 & 0 & 0.0 & 0 & 0.0 \\
\hline AF/GANA & 0 & 0.0 & 0 & 0.0 & 0 & 0.0 & 0 & 0.0 & 0 & 0.0 & 1 & 4.2 \\
\hline AF/GA/SS & 0 & 0.0 & 0 & 0.0 & 0 & 0.0 & 4 & 6.8 & 3 & 4.8 & 0 & 0.0 \\
\hline Total & 20 & 100 & 33 & 100 & 51 & 100 & 59 & 100 & 62 & 100 & 24 & 100 \\
\hline
\end{tabular}

${ }^{a}$ superscripts indicate the corresponding numbers of adult ticks with the respective infection.

${ }^{b}$ calculated from the total number of infected ticks used for genospecies identification in the respective year and from the respective site.

other genospecies between $3.4 \%$ and $20.8 \%$ in the different plant communities. Double infections were present in only up to $10.2 \%$ of infected ticks, mainly including $B$. garinii, $B$. afzelii and $B$. valaisiana. At all sites, $B$. burgdorferi s.s. was detected as a single infection. Comparing double infections of both years $B$. afzelii and $B$. garinii appeared always in combination with three of the other four genospecies. Four ticks with triple infections in the Luzulo-Fagetum milietosum contained the same genospecies combination as the ticks in 2007 from the Galio-Fagetum typicum. In the latter biotope, a new combination with $B$. afzelii, B. garinii and B. valaisiana occurred in one tick.
Climate conditions in the region of Bonn between 1987 and 2008

Climate records of the region of Bonn, near the Siebengebirge, revealed no striking differences in the mean monthly air temperatures between any year of 1987 until 2008 (One Way ANOVA, p > 0.05, Table 4). Furthermore, no statistically significant differences in the average monthly winter air temperatures from November to February before the collection periods in 1987, 1989, 2003, 2007 and 2008 were evident (KruskalWallis test, $\mathrm{p}>0.05$, Table 4).

Precipitation levels in the region of Bonn during the tick collection months differed significantly between

Table 4 Mean monthly air temperatures $\left[{ }^{\circ} \mathrm{C}\right] 2 \mathrm{~m}$ above the soil near the Siebengebirge ${ }^{\mathrm{a}}$ in different years

\begin{tabular}{ccccccccccccccc}
\hline & Jan & Feb & Mar & Apr & May & Jun & Jul & Aug & Sep & Oct & Nov & Dec & Year & Winter months $\mathbf{b}^{\mathbf{2}}$ \\
\hline 1986 & 2.6 & -4.1 & 4.9 & 6.9 & 14.9 & 17.7 & 18.3 & 17.1 & 11.5 & 11.6 & 7.6 & 4.3 & 9.4 & - \\
1987 & -3.5 & 1.8 & 2.3 & 12.6 & 10.3 & 14.8 & 18.0 & 16.8 & 15.8 & 10.8 & 6.1 & 3.9 & 9.1 & 2.6 \\
1988 & 5.8 & 4.0 & 4.9 & 9.4 & 15.9 & 20.6 & 17.4 & 17.7 & 14.1 & 11.1 & 5.2 & 6.5 & 11.1 & - \\
1989 & 4.1 & 4.4 & 8.8 & 11.4 & 15.6 & 16.0 & 19.4 & 18.3 & 15.5 & 12.1 & 5.0 & 4.7 & 11.3 & 5.1 \\
2002 & 3.2 & 7.0 & 7.3 & 9.7 & 14.3 & 18.0 & 17.9 & 18.8 & 13.9 & 10.0 & 8.3 & 3.9 & 11.0 & - \\
2003 & 1.7 & 1.4 & 8.1 & 10.3 & 14.6 & 19.7 & 19.8 & 20.8 & 14.9 & 7.6 & 8.6 & 3.7 & 10.9 & 3.8 \\
2006 & 0.2 & 1.8 & 3.8 & 9.1 & 14.5 & 17.8 & 23.3 & 16.2 & 18.4 & 14.0 & 8.9 & 5.8 & 11.2 & - \\
2007 & 6.5 & 6.2 & 7.9 & 13.8 & 15.3 & 18.0 & 17.8 & 17.0 & 13.5 & 9.8 & 5.7 & 3.3 & 11.2 & 6.9 \\
2008 & 5.9 & 5.1 & 5.8 & 8.8 & 16.5 & 17.3 & 18.2 & 18.2 & 13.0 & 10.2 & 6.5 & 2.0 & 10.6 & 5.0
\end{tabular}

${ }^{a}$ Data were obtained from the weather station Cologne/Bonn (no. 10513) of the Deutscher Wetterdienst.

${ }^{b}$ The mean temperature of the winter months were determined by calculating the mean monthly temperature from November of the previous year to February of the following year stated in the beginning of each line. For example, for 2007 the mean average temperature of the winter months was calculated from November 2006 until February 2007. 
the collection years 1978, 1989, 2003, 2007 and 2008 (Kruskal-Wallis test, $\mathrm{p}<0.05$ ) with high precipitation levels from May to August in 1987 and 2007 (Table 5). Significantly higher precipitation levels were also recorded in 2007 compared to 2003 (Mann-Whitney U test, $\mathrm{p}<0.05)$.

\section{Discussion}

Comparison of tick densities and climate conditions between the different study years

Long-term investigations on the distribution of the tick I. ricinus and on Borrelia infection rates in these ticks are rare, and in Germany these investigations have been only performed since 1987 in the nature reserve Siebengebirge, a very popular recreation area of the Bonn-Cologne region. The nature reserve possesses a very species-rich vegetation with approximately 100 different plant communities [51] which support the development of I. ricinus differently [8]. According to a study monitoring tick densities including Geographic Information Systems (GIS) in 2003, $57 \%$ of the total area of the nature reserve possesses very high $\left(\geq 51\right.$ ticks $\left./ 100 \mathrm{~m}^{2}\right)$ to medium tick densities (11-40 ticks/100m ${ }^{2}$ ) [8]. Comparing exactly the same sites examined since 1987, tick densities changed considerably between 1987/89 and 2008 (Figure 3). In the Fraxino-Aceretum pseudoplatani (covering $0.3 \%$ of the nature reserve) the number of ticks/year $/ 100 \mathrm{~m}^{2}$ decreased from 1987 until 2003 to a minimum of 9 ticks $/ 100 \mathrm{~m}^{2}$ in 2003 and increased about 8-fold until 2008. In the Luzulo-Fagetum milietosum which covers $3 \%$ of the total area of the nature reserve $(24 \%$ including all Luzulo-Fagetum sub-associations), the tick population density enormously decreased between 1987 and 2003, but then increased continuously to a 3 -fold higher density compared to 2003. In the GalioFagetum typicum, the abundance increased continuously from 13 ticks $/ 100 \mathrm{~m}^{2}$ in 1987 to 146 ticks $/ 100 \mathrm{~m}^{2}$ in 2008. An assessment of the tick numbers for the entire Siebengebirge according to the GIS evaluation

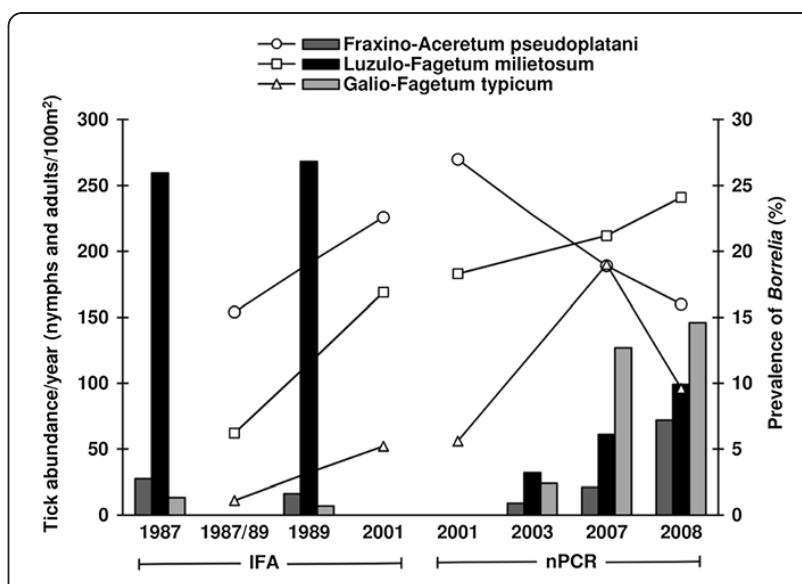

Figure 3 Abundances of ticks at three plant communities in the Siebengebirge and Borrelia burgdorferi s.l. prevalences from 1987 to 2008. Abundances are presented as columns: FraxinoAceretum pseudoplatani (dark grey), the Luzulo-Fagetum milietosum (black) and the Galio-Fagetum typicum (light grey). Monthly tick abundances per $100 \mathrm{~m}^{2}$ of study site from May to September of each study year were calculated; in 2001 tick densities were not determined [15]. Borrelia prevalences for the Fraxino-Aceretum pseudoplatani, the Luzulo-Fagetum milietosum and the GalioFagetum typicum, are presented as circles, squares and triangles, respectively. Tick samples from 1987/89 and 2001 were examined for Borrelia infection by the immunofluorescence assay (IFA) using the same experimental protocol $[15,38]$. The same ticks used for IFA in 2001 were also analyzed for Borrelia infection by nested PCR (nPCR) [15]. Additionally, the same nPCR approach from 2001 was employed to analyze I. ricinus in 2007 and 2008. Accordingly, Borrelia prevalences from 1987/89 were compared with results from 2001, and 2001 prevalence data were compared with the data from 2007 and 2008. Borrelia infection rates were not determined in 2003 [8].

of $I$. ricinus in the Siebengebirge by Schwarz et al. [8] suggested that the increase in tick numbers may have a huge impact on the total number of ticks in the entire Siebengebirge because the Galio-Fagetum typicum is the third largest plant community, covering $10 \%$ of the total area of the nature reserve [52]. However, for example, differences in the host cenosis at the same plant communities in different areas of the Siebengebirge can change the distribution of tick populations.

Table 5 Monthly precipitation heights $[\mathrm{mm}]$ near the Siebengebirge ${ }^{a}$ in different years

\begin{tabular}{|c|c|c|c|c|c|c|c|c|c|c|c|c|c|c|}
\hline & Jan & Feb & Mar & Apr & May & Jun & Jul & Aug & Sep & Oct & Nov & Dec & Year & Summer months \\
\hline 1987 & 59.6 & 68.9 & 104.0 & 39.0 & 70.6 & 123.0 & 126.8 & 83.3 & 50.2 & 38.2 & 80.6 & 42.3 & 73.9 & 100.9 \\
\hline 1988 & 72.3 & 68.1 & 160.0 & 31.0 & 19.2 & 49.9 & 134.8 & 27.1 & 52.2 & 58.2 & 85.9 & 112.1 & 72.6 & 57.8 \\
\hline 1989 & 27.6 & 57.1 & 65.8 & 103.1 & 26.3 & 61.1 & 49.9 & 67.9 & 37.8 & 62.6 & 38.4 & 95.1 & 57.7 & 51.3 \\
\hline 2002 & 56.3 & 122.0 & 58.9 & 75.1 & 44.8 & 43.9 & 89.4 & 97.2 & 29.4 & 89.9 & 93.5 & 90.5 & 74.2 & 68.8 \\
\hline 2003 & 77.1 & 29.2 & 43.5 & 43.4 & 55.2 & 72.7 & 53.4 & 55.3 & 50.8 & 95.1 & 45.6 & 54.0 & 56.3 & 59.2 \\
\hline 2006 & 25.3 & 64.6 & 79.3 & 68.4 & 99.3 & 37.5 & 17.0 & 96.5 & 32.8 & 38.0 & 85.0 & 55.9 & 58.3 & 62.6 \\
\hline 2007 & 82.4 & 59.8 & 53.5 & 1.6 & 129.6 & 105.8 & 127.8 & 193.0 & 59.9 & 33.2 & 70.8 & 52.2 & 80.8 & 139.1 \\
\hline 2008 & 35.6 & 38.5 & 71.0 & 64.0 & 36.6 & 89.8 & 131.7 & 62.9 & 52.1 & 80.4 & 45.1 & 55.9 & 63.6 & 80.3 \\
\hline
\end{tabular}

${ }^{a}$ Data were obtained from the weather station Cologne/Bonn (no. 10513) of the Deutscher Wetterdienst.

${ }^{b}$ The mean precipitation heights of the summer months were obtained by calculating the monthly precipitation from May to August of the same year. 
Temperature is one of the most important abiotic factors for tick development [5,53,54], and global warming during the last two decades of the $20^{\text {th }}$ century is suggested to be one of the reasons for increasing tick abundances in Sweden or Great Britain [4,55]. Ticks were collected at similar air temperature conditions from May to September in all years $[8,15,38]$ with a minimum recorded temperature of $14.7^{\circ} \mathrm{C}$ in August 2007 in the Luzulo-Fagetum milietosum (data not shown). Additionally, air temperatures of the region of Bonn did not significantly differ between the years. However, in comparison to other tick collection seasons relatively high air temperatures from November 2006 until April $2007\left(8.9^{\circ} \mathrm{C}-13.9^{\circ} \mathrm{C}\right)$ were recorded that may have caused a higher survival rate of ticks in 2006 as well as a stronger increase of tick population densities in spring 2007 and thus an overall increase in abundances during the entire tick season in 2007.

In addition to temperature, humidity affects the development of ticks. The relative humidity at the three sites and during the tick collections differed between the years [8,15,38]. In 1987, 1989 and 2001, ticks were collected at a minimum of $80 \%$ relative humidity at the sites, and in the years 2003, 2007 and 2008 minimum relative humidities of $57 \%$ [8], $45 \%$ and $52 \%$ (Table 1), respectively, were recorded at the biotopes. During all 15 tick collections in 2003 less than 70\% relative humidity occurred at all field sites [52], and in 2007 only in 7 out of 15 collections more than $70 \%$ relative humidity was recorded (data not shown). In 2008, a minimum of $70 \%$ relative humidity was reached during 6 out of 15 tick collections. Although from 2003 to 2008 in $62 \%$ of all collections drier climatic conditions occurred compared to 1987 and 1989, higher tick abundances were determined in some of the biotopes between 2003 and 2008 (Figure 3). The saturation deficit that depends on the air temperature and the relative humidity influences the questing behavior of ticks $[5,56]$. Therefore, numbers of questing ticks increased until a certain limit of the saturation deficit [57]. This may explain the increase in questing ticks at the different study sites from 2003 to 2008. However, the high air temperatures in summer 2003 most likely corresponded with the lower yearly tick densities in the Fraxino-Aceretum pseudoplatani and Luzulo-Fagetum milietosum (Figure 3), because the saturation deficit was very high at these sites, and a high saturation deficit can rapidly decrease the numbers of questing ticks [56].

In a correlation of abiotic factors and tick abundances, the number of host seeking ticks rose significantly with rising soil water content in 2003 [8] and that may also explain the increase in tick numbers in 2007. Comparing all three different plant communities, the FraxinoAceretum pseudoplatani soil had the lowest water content and this correlated with low numbers of collected ticks [8]. The soil water content is affected by the precipitation. Overall higher precipitation levels in the region of Bonn in 2007 compared to 2003 combined with the higher air temperatures during the winter and spring may explain the higher tick numbers in 2007 in comparison to 2003. In addition, the soil water content of the different sites was 1-2 times higher in May and June 2007 (data not shown) than in the dry summer 2003. Furthermore, the optimal abiotic conditions in summer 2007 most likely caused a strong increase in the density of the tick population which was not strongly reduced by the mild winter 2007/2008 (Table 4) and resulted in higher numbers of questing ticks in 2008, respectively. These data indicate an effect of global warming on the number of ticks, but a continuous monitoring of tick densities covering several years and a determination of soil water contents are necessary for a better conclusion.

\section{Comparison of Borrelia prevalences between the study years}

Borrelia infection rates were sometimes positively correlated with tick densities [58,59]. However in the Siebengebirge, the prevalences of Borrelia decreased in the Fraxino-Aceretum pseudoplatani and the Galio-Fagetum typicum from 2007 to 2008, whereas the total number of ticks increased in these biotopes (Figure 3). Only the Luzulo-Fagetum milietosum showed consistently increasing infection rates of ticks with Borrelia from 1987 to 2001 (IFA data comparison) and from 2001 to 2008 (nested PCR data) as well as increasing tick abundances since 1987 (apart from the exceptional high abundances in that biotope in 1987 and 1989) $[8,15]$. Since climate factors cannot explain this phenomenon, biotic factors should be considered. Tick populations strongly depend on their hosts and infections with Borrelia can only be obtained from hosts [60-62]. Rabbits, foxes, roe and red deer, wild boar, mice and voles are abundant in the Siebengebirge and hosts of $I$. ricinus. Of these, Apodemus sylvaticus, A. flavicollis and Clethrionomys glareolus have been confirmed as reservoir hosts of Borrelia in the nature reserve [37]. Reservoir hosts of Borrelia differ considerably in their competence to acquire the infection and to enable a multiplication of the spirochetes for a successful transmission [61]. The reservoir potential of Apodemus spp. and C. glareolus differed even between biotopes in the Siebengebirge [37] which may be caused by differing host immune responses, for example by tick density-dependent resistance of the host against tick feeding. Another reservoir host for $B$. burgdorferi s.l. is the wild boar [63-66]. In the Siebengebirge, the numbers increased enormously during the last 50 years [67], but hunted boars were not strongly infested by ticks $[68,69]$. Much 
stronger infestation was seen in roe deer, which are abundant in the Siebengebirge, thus supporting tick populations [70]. However, roe deer are not a competent host for B. burgdorferi s.l. [71,72], most likely resulting in a so called dilution effect of Borrelia [73].

Such investigations are also required to explain the increased number of multiple infections with Borrelia in I. ricinus from the Siebengebirge. In 2007, significantly more ticks possessed multiple infections than in 2001 $\left(x^{2}=7.7, \mathrm{df}=2, \mathrm{p}<0.05\right)$ [15]. In 2001, only seven double infections with Borrelia were detected [15], whereas 7 -fold and 4-fold more multiple infections were recorded in 2007 and 2008, respectively. Increased numbers of ticks within the last few years may have given rise to the probability of more ticks co-feeding on the same host and this may have led to an increased exchange of different genospecies between host and ticks resulting in a higher burden of different Borrelia genotypes per tick and host [74] However, the lower percentages of double infections in the Siebengebirge in 2008 in comparison to 2007 indicate the existence of specific factors and no general trend. For the first time in the Siebengebirge, triple infections were detected; one type of infection in 2007 and two different types of Borrelia combination in 2008. In 1987/89 no discrimination between single and multiple Borrelia infections were carried out. Initially, more single than double infections of ticks with Borrelia were reported for different sites in Europe [18,75,76]. However, not only in the Siebengebirge, but also in Ireland and Denmark the percentages of mixed infections increased, and even quadruple infections occurred [77,78]. Multiple infections can increase the risk of infections by Lyme disease since the chance of infections of a competent vector is increased.

\section{Comparison of Borrelia genospecies between 2001, 2007 and 2008}

Estimations of the infection risk require not only a determination of the numbers of ticks and the infection rates with $B$. burgdorferi s.l., but also determinations of the genospecies. B. afzelii, B. garinii and B. valaisiana are the three most abundant species in Europe [29]. This is also the case in the Siebengebirge, but the prevalence of $B$. burgdorferi genospecies has changed during the few last years. In 2001, at all three sites the most prominent genospecies was $B$. valaisiana (infection rate of 43.1\%) [15], whereas in 2007 B. garinii and B. afzelii were detected in every second tick, and in $2008 \mathrm{~B}$. garinii was the dominant species. Also changes of lowabundant genospecies occurred within the two collection years of the present study: For example, in $2007 B$. burgdorferi s.s. was only detected in 7 out of 137 infected ticks, but one year later this species was found in 35 out of 116 ticks. Also B. valaisiana was rarely found in 2007 but in $19.8 \%$ of Borrelia infections in 2008.

Differences in the genospecies composition were also evident between the three study sites. In the FraxinoAceretum pseudoplatani, B. valaisiana as dominant species in 2001 did not re-appear to this extent in the present study [15]. Only the Luzulo-Fagetum milietosum showed a stable dominance of B. garinii with similar infection rates in all years. In the Galio-Fagetum typicum, in 2001 B. garinii and B. afzelii predominated, in 2007 only B. afzelii, and in 2008 similar numbers of ticks were infected with B. garinii, B. valaisana and B. afzelii. Such differences in the distribution of genospecies seem to be caused by differences in the host cenosis [29] and be based on different competences of vertebrate hosts for the respective genospecies. $B$. afzelii is mainly found in rodents such as Apodemus sp., and B. garinii and $B$. valaisiana are associated with birds [31]. The complement system of rodents completely lyses different genotypes of $B$. garinii and B. valaisiana but not B. afzelii [79]. Vice versa, in birds the complement system lyses $B$. afzelii, but not B. garinii and B. valaisiana [79]. Comparing the reservoir capacity of different birds, pheasants (Phasianus colchicus) and passerines such as the European blackbird (Turdus merula) and the American robin ( $T$. migratorius) were positively associated with Borrelia infections [80-82]. Both, rodents and birds are competent reservoir hosts of Borrelia burgdorferi s.s. [32]. In the Siebengebirge in all study years, the two bird genospecies, B. garinii and B. valaisiana, together predominated. Thus, birds in the Siebengebirge seem to be the most successful reservoir host for Borrelia, a phenomenon that was also suggested for 2001 [15]. Passerine birds are widely distributed in the Siebengebirge, and thus they have a high impact on the density of ticks.

$B$. lusitaniae was detected for the first time in the Siebengebirge in 2007. We cannot exclude it for 2001 since DNA probes for B. lusitaniae, B. spielmanii and B. bissettii were not used in that year. However, only 4 out of 65 Borrelia-positive tick samples in 2001 reacted only with the complex specific B. burgdorferi s.l. probe [15]. Initially, this genospecies was classified as nonpathogenic for humans because this species was not detected in humans but only found in animal hosts $[83,84]$. However, serious symptoms of Lyme borreliosis were induced in mice infected by $B$. lusitaniae [85], and recently the first isolate of this genospecies was found in a woman suffering from chronic skin lesions in Portugal [28]. Thus, B. lusitaniae represents a new Borrelia genospecies with a new risk for visitors of the Siebengebirge to be infected with Lyme disease. B. lusitaniae was frequently present in ticks from Mediterranean countries such as Portugal (first record), Tunisia and Morocco $[84,86,87]$. It was also found in the Czech Republic, 
Poland, Slovakia, Moldavia, Ukraine, Spain, France, Switzerland and South Germany [36,75,83,88-91]. The recent identifications in Denmark and Sweden demonstrated the ability of this genospecies to establish even in northern Europe [77,92]. In the Siebengebirge, $B$. lusitaniae was found in 15 ticks (13 nymphs and one adult from the Luzulo-Fagetum milietosum and one from the Fraxino-Aceretum pseudoplatani). The latter site was near the Luzulo-Fagetum milietosum. Half of these ticks were co-infected with $B$. garinii and one tick with $B$. valaisiana indicating that birds may have introduced this species to the Siebengebirge; a similar observation was made in Switzerland [93]. Birds are considered as main reservoir hosts for $B$. lusitaniae [35], but sand lizards (Lacerta agilis) and common wall lizards (Podarcis muralis) were also infected with B. lusitaniae in Germany [36]. These two lizard species exist in the Siebengebirge, but they are rare and thus presumably less important for the distribution of $B$. lusitaniae in the Siebengebirge. Since almost all $B$. lusitaniae were detected in May and June of 2007 (apart from one infected tick in the Fraxino-Aceretum pseudoplatani in September) but not again in 2008, and since the distribution of Borrelia is linked to the migration of birds [31] future investigations in Borrelia transmission in the Siebengebirge should consider migratory birds as potential hosts of Borrelia. The maintenance of $B$. lusitaniae in the local bird fauna of the Siebengebirge is rather unlikely because in that case $B$. lusitaniae should have been detected frequently alongside with B. garinii and B. valaisiana in ticks. However, although recently Norte et al. [94] confirmed $B$. lusitaniae in questing $I$. ricinus they could never detect this Borrelia species in the local bird fauna in Portugal nor in migratory birds. Instead, two Borrelia isolates were identical to $B$. lusitaniae detected in mice skin in Portugal [95] and in ticks feeding on lizards from central Europe, Madeira and Portugal [36,96,97]. Thus, mice and lizards may maintain $B$. lusitaniae, and birds only play a minor, temporary role in the $B$. lusitaniae distribution. However, mice commonly occur in the Luzulo-Fagetum milietosum and Fraxino-Aceretum pseudoplatani and nevertheless $B$. lusitaniae was only detected for a short time in 2007. Furthermore, Amore et al. [98] found B. lusitaniae only in ticks feeding on lizards, but not in ticks feeding on mice and birds. Thus, the distribution and maintenance of $B$. lusitaniae remains unclear and further investigations are needed including the analysis of ticks feeding on mice, lizards and birds in the Siebengebirge.

\section{Conclusions}

Over the last two centuries tick densities have increased in the Siebengebirge, a dense forested nature reserve providing excellent abiotic and biotic conditions for ticks, without changes of the biotopes by human activities. These increases were most likely favored by climatic conditions. Although Borrelia infection prevalences did not increase simultaneously with increasing tick densities in all biotopes, significantly higher multiple infections of ticks with Borrelia occurred in 2007 than in 2001; for the first time triple infections with Borrelia were detected in 2007 and 2008 in the Siebengebirge. Furthermore, a new Borrelia species, B. lusitaniae, has been introduced to the Siebengebirge. Thus, the risk for visitors, woodmen, hunters, farmers and animals of the nature reserve Siebengebirge of being exposed to tick bites increased strongly since 1987, however, the risk of being infected by Lyme disease did not increase consequently simultaneously. Nevertheless, the increase of multiple Borrelia infections in ticks may represent a new potential risk factor.

\section{Competing interests}

The authors declare that they have no competing interests.

\section{Authors' contributions}

AS, GAS and LG drafted the manuscript. AS and GAS designed the study and AA collected the ticks in the Siebengebirge, Germany. AS and CB performed the tick examinations of the samples in 2007, and VH and ZV carried out all further experiments of samples from 2008 and all genotyping experiments. All authors read and approved the final manuscript.

\section{Acknowledgements}

The authors thank Carina Schleiden for her assistance in the tick collections and Kathrin Hartelt and Rainer Oehme for providing Borrelia strains as positive control samples for the experiments. A.S. was funded by the Alexander von Humboldt Foundation (Feodor Lynen Research Fellowship). We also acknowledge the financial support of the Grant Agency of the Czech Republic (GACR grant no. 206/09/H026), the Ministry of Education, Youth and Sports of the Czech Republic (MSMT grant no. LC 06009 and MSM 6007665801), the European Union (FP7 HEALTH, ANTIGONE project 278976) and the Academy of Sciences of the Czech Republic (grant no. Z60220518). We are also very grateful for the financial support of parts of this study by WEPA APOTHEKENBEDARF GmbH \& Co KG, Hillscheid, Germany.

\section{Author details}

${ }^{1}$ Institute of Parasitology, Biology Centre, Academy of Sciences of Czech Republic, České Budějovice, Czech Republic. ${ }^{2}$ Group Zoology/Parasitology, Ruhr-Universität Bochum, Bochum, Germany. ${ }^{3}$ Faculty of Science, University of South Bohemia, České Budĕjovice, Czech Republic.

Received: 13 May 2012 Accepted: 4 November 2012

Published: 21 November 2012

\section{References}

1. de Castro JJ: Sustainable tick and tickborne disease control in livestock improvement in developing countries. Vet Parasitol 1997, 71:77-97.

2. Alciati S, Belligni E, Del Colle S, Pugliese A: Human infections ticktransmitted. Panminerva Med 2001, 43:295-304.

3. Pérez-Eid C, Rodhain F: Biologie d'Ixodes ricinus L., 1758. I. Ecologie, cycle évolutif. Bull Soc Pathol Exot Filiales 1977, 70:187-192.

4. Lindgren $E$, Tälleklint $L$, Polfeldt $T$ : Impact of climatic change on the northern latitude limit and population density of the diseasetransmitting European tick Ixodes ricinus. Environ Health Perspect 2000, 108:119-123.

5. Perret $J$, Guigoz E, Rais O, Gern L: Influence of saturation deficit and temperature on Ixodes ricinus tick questing activity in a Lyme borreliosisendemic area (Switzerland). Parasitol Res 2000, 86:554-557. 
6. Hubálek Z, Halouzka J, Juricová Z: Host-seeking activity of ixodid ticks in relation to weather variables. J Vector Ecol 2003, 28:159-165.

7. Lindström A, Jaenson TG: Distribution of the common tick, Ixodes ricinus (Acari: Ixodidae), in different vegetation types in southern Sweden. J Med Entomol 2003, 40:375-378.

8. Schwarz A, Maier WA, Kistemann T, Kampen $\mathrm{H}$ : Analysis of the distribution of the tick Ixodes ricinus L. (Acari: Ixodidae) in a nature reserve of western Germany using Geographic Information Systems. Int J Hyg Environ Health 2009, 212:87-96.

9. Materna J, Daniel M, Danielová V: Altitudinal distribution limit of the tick Ixodes ricinus shifted considerably towards higher altitudes in central Europe: results of three years monitoring in the Krkonose Mts. (Czech Republic). Cent Eur J Public Health 2005, 13:24-28.

10. Stanek G: Büchse der Pandora: Krankheitserreger in Ixodes ricinus-Zecken in Mitteleuropa. Wien Klin Wochenschr 2009, 121:673-683.

11. Mejlon HA, Jaenson TGT: Questing behaviour of Ixodes ricinus ticks (Acari: Ixodidae). Exp Appl Acarol 1997, 21:747-754

12. Randolph SE: Evidence that climate change has caused 'emergence' of tick-borne diseases in Europe? Int J Med Microbiol 2004 293(Suppl 37):5-15.

13. Humair P, Gern L: The wild hidden face of Lyme borreliosis in Europe. Microbes Infect 2000, 2:915-922.

14. Hubálek Z, Halouzka J: Prevalence rates of Borrelia burgdorferi sensu lato in host-seeking Ixodes ricinus ticks in Europe. Parasitol Res 1998, 84:167-172.

15. Kampen H, Rötzel DC, Kurtenbach K, Maier WA, Seitz HM: Substantial rise in the prevalence of Lyme borreliosis spirochetes in a region of western Germany over a 10-year period. Appl Environ Microbiol 2004, 70:1576-1582.

16. Jensen PM, Jespersen JB: Five decades of tick-man interaction in Denmark-an analysis. Exp Appl Acarol 2005, 35:131-146.

17. Gern L, Estrada-Peña A, Frandsen F, Gray JS, Jaenson TG, Jongejan F, Kahl O, Korenberg E, Mehl R, Nuttall PA: European reservoir hosts of Borrelia burgdorferi sensu lato. Zentralbl Bakteriol 1998, 287:196-204.

18. Hubálek Z, Halouzka J: Distribution of Borrelia burgdorferi sensu lato genomic groups in Europe, a review. Eur J Epidemiol 1997, 13:951-957.

19. Richter D, Postic D, Sertour N, Livey I, Matuschka FR, Baranton G: Delineation of Borrelia burgdorferi sensu lato species by multilocus sequence analysis and confirmation of the delineation of Borrelia spielmanii sp. nov. Int J Syst Evol Microbiol 2006, 56:873-881.

20. Margos G, Vollmer SA, Cornet M, Garnier M, Fingerle V, Wilske B, Bormane A, Vitorino L, Collares-Pereira M, Drancourt M, Kurtenbach K: A new Borrelia species defined by multilocus sequence analysis of housekeeping genes. Appl Environ Microbiol 2009, 75:5410-5416.

21. Wilske B, Preac-Mursic V, Gobel UB, Graf B, Jauris S, Soutschek E, Schwab E, Zumstein G: An OspA serotyping system for Borrelia burgdorferi based on reactivity with monoclonal antibodies and OspA sequence analysis. J Clin Microbiol 1993, 31:340-350.

22. van Dam AP, Kuiper H, Vos K, Widjojokusumo A, de Jongh BM, Spanjaard L, Ramselaar AC, Kramer MD, Dankert J: Different genospecies of Borrelia burgdorferi are associated with distinct clinical manifestations of Lyme borreliosis. Clin Infect Dis 1993, 17:708-717.

23. Rijpkema SG, Tazelaar DJ, Molkenboer MJ, Noordhoek GT, Plantinga G, Schouls LM, Schellekens JF: Detection of Borrelia afzelii, Borrelia burgdorferi sensu stricto, Borrelia garinii and group VS116 by PCR in skin biopsies of patients with erythema migrans and acrodermatitis chronica atrophicans. Clin Microbiol Infect 1997, 3:109-116.

24. Diza E, Papa A, Vezyri E, Tsounis S, Milonas I, Antoniadis A: Borrelia valaisiana in cerebrospinal fluid. Emerg Infect Dis 2004, 10:1692-1693.

25. Strle F, Picken RN, Cheng Y, Cimperman J, Maraspin V, Lotric-Furlan S, RuzicSabljic E, Picken MM: Clinical findings for patients with Lyme borreliosis caused by Borrelia burgdorferi sensu lato with genotypic and phenotypic similarities to strain 25015. Clin Infect Dis 1997, 25:273-280.

26. Rudenko N, Golovchenko M, Mokrácek A, Piskunová N, Ruzek D, Mallatová N, Grubhoffer L: Detection of Borrelia bissettii in cardiac valve tissue of a patient with endocarditis and aortic valve stenosis in the Czech Republic. J Clin Microbiol 2008, 46:3540-3543.

27. Fingerle $V$, Schulte-Spechtel UC, Ruzic-Sabljic E, Leonhard S, Hofmann $H_{\text {, }}$ Weber K, Pfister K, Strle F, Wilske B: Epidemiological aspects and molecular characterization of Borrelia burgdorferi s.l. from southern Germany with special respect to the new species Borrelia spielmanii sp. nov. Int J Med Microbiol 2008, 298:279-290.
28. Collares-Pereira M, Couceiro S, Franca I, Kurtenbach K, Schäfer SM, Vitorino L, Gonçalves L, Baptista S, Vieira ML, Cunha C: First isolation of Borrelia Iusitaniae from a human patient. J Clin Microbiol 2004, 42:1316-1318.

29. Kurtenbach K, De Michelis S, Sewell HS, Etti S, Schäfer SM, Hails R, CollaresPereira M, Santos-Reis M, Hanincová K, Labuda M, et al: Distinct combinations of Borrelia burgdorferi sensu lato genospecies found in individual questing ticks from Europe. Appl Environ Microbiol 2001, 67:4926-4929.

30. Richter D, Klug B, Spielman A, Matuschka FR: Adaptation of diverse lyme disease spirochetes in a natural rodent reservoir host. Infect Immun 2004, 72:2442-2444.

31. Kurtenbach K, De Michelis S, Sewell HS, Etti S, Schäfer SM, Holmes E, Hails R, Collares-Pereira M, Santos-Reis M, Hanincová K, et al: The key roles of selection and migration in the ecology of Lyme borreliosis. Int J Med Microbiol 2002, 291:152-154.

32. Hanincová K, Kurtenbach K, Diuk-Wasser M, Brei B, Fish D: Epidemic spread of Lyme borreliosis, northeastern United States. Emerg Infect Dis 2006, 12:604-611.

33. Margos G, Hojgaard A, Lane RS, Cornet M, Fingerle V, Rudenko N, Ogden N, Aanensen DM, Fish D, Piesman J: Multilocus sequence analysis of Borrelia bissettii strains from North America reveals a new Borrelia species, Borrelia kurtenbachii. Ticks Tick Borne Dis 2010, 1:151-158.

34. Richter D, Schlee DB, Allgöwer R, Matuschka FR: Relationships of a novel Lyme disease spirochete, Borrelia spielmanii sp. nov., with its hosts in Central Europe. Appl Environ Microbiol 2004, 70:6414-6419.

35. Wodecka B, Skotarczak B: First isolation of Borrelia lusitaniae DNA from Ixodes ricinus ticks in Poland. Scand J Infect Dis 2005, 37:27-34.

36. Richter D, Matuschka FR: Perpetuation of the Lyme disease spirochete Borrelia lusitaniae by lizards. Appl Environ Microbiol 2006, 72:4627-4632.

37. Kurtenbach K, Kampen H, Dizij A, Arndt S, Seitz HM, Schaible UE, Simon MM: Infestation of rodents with larval Ixodes ricinus (Acari: Ixodidae) is an important factor in the transmission cycle of Borrelia burgdorferi s.l. in German woodlands. J Med Entomol 1995, 32:807-817.

38. Kurtenbach K: Epidemiologische und immunologische Untersuchungen zur Rolle von Zecken (Ixodoidea, Ixodidae) und Wildnagern (Rodentia) im Infektionskreislauf von Borrelia burgdorferi (Spirochaetaceae), PhD thesis: University of Bonn, Faculty of Mathematics and Natural Sciences; 1992

39. Hillyard PD: Ticks of north-west Europe: keys and notes for identification of species. In Synopses of the British Fauna (New Series). No. 52. Edited by Barnes RSK, Crothers JH. Shrewsbury: Field Studies Council; 1996:178.

40. Rauter C, Oehme R, Diterich I, Engele M, Hartung T: Distribution of clinically relevant Borrelia genospecies in ticks assessed by a novel, single-run, real-time PCR. J Clin Microbiol 2002, 40:36-43.

41. Walsh PS, Metzger DA, Higuchi R: Chelex 100 as a medium for simple extraction of DNA for PCR-based typing from forensic material. Biotechniques 1991, 10:506-513.

42. Guy EC, Stanek G: Detection of Borrelia burgdorferi in patients with Lyme disease by the polymerase chain reaction. J Clin Pathol 1991, 44:610-611.

43. Barbour AG: Isolation and cultivation of Lyme disease spirochetes. Yale J Biol Med 1984, 57:521-525.

44. Rijpkema SG, Molkenboer MJ, Schouls LM, Jongejan F, Schellekens JF: Simultaneous detection and genotyping of three genomic groups of Borrelia burgdorferi sensu lato in Dutch Ixodes ricinus ticks by characterization of the amplified intergenic spacer region between $5 \mathrm{~S}$ and 23S rRNA genes. J Clin Microbiol 1995, 33:3091-3095.

45. Liebisch G, Sohns B, Bautsch W: Detection and typing of Borrelia burgdorferi sensu lato in Ixodes ricinus ticks attached to human skin by PCR. J Clin Microbiol 1998, 36:3355-3358.

46. Schwartz I, Wormser GP, Schwartz JJ, Cooper D, Weissensee P, Gazumyan A, Zimmermann E, Goldberg NS, Bittker S, Campbell GL, Pavia CS: Diagnosis of early Lyme disease by polymerase chain reaction amplification and culture of skin biopsies from erythema migrans lesions. J Clin Microbiol 1992, 30:3082-3088.

47. Gern L, Douet V, Lopez Z, Rais O, Cadenas FM: Diversity of Borrelia genospecies in Ixodes ricinus ticks in a Lyme borreliosis endemic area in Switzerland identified by using new probes for reverse line blotting. Ticks Tick Borne Dis 2010, 1:23-29.

48. Alekseev AN, Dubinina HV, Van De Pol I, Schouls LM: Identification of Ehrlichia spp. and Borrelia burgdorferi in Ixodes ticks in the Baltic regions of Russia. J Clin Microbiol 2001, 39:2237-2242. 
49. Burri C, Moran Cadenas F, Douet V, Moret J, Gern L: Ixodes ricinus density and infection prevalence of Borrelia burgdorferi sensu lato along a Northfacing altitudinal gradient in the Rhone Valley (Switzerland). Vector Borne Zoonotic Dis 2007, 7:50-58.

50. Priem S, Rittig MG, Kamradt T, Burmester GR, Krause A: An optimized PCR leads to rapid and highly sensitive detection of Borrelia burgdorferi in patients with Lyme borreliosis. J Clin Microbiol 1997, 35:685-690.

51. Bouillon B, Felinks B, Hand R, Krause S, Röhlinger-Nord B, Schuhmacher W: Floristisch-vegetationskundliche Bestandsaufnahme und Bewertung des NSG Siebengebirge: Mit Empfehlungen zur Entwicklung und Pflege. Siegburg: Untere Landschaftsbehörde des Rhein-Sieg-Kreises; 1994.

52. Schwarz A: GIS-gestützte Untersuchung zur Risikoabschätzung der Verbreitung von Ixodes ricinus L. (Acari: Ixodidae) im Naturpark Siebengebirge bei Bonn, Diploma thesis: University of Bonn, Faculty of Mathematics and Natural Sciences; 2004

53. Gray JS: The development and seasonal activity of the tick Ixodes ricinus: a vector of Lyme borreliosis. Rev Med Vet Entomol 1991, 79:323-333.

54. Randolph SE: Tick ecology: processes and patterns behind the epidemiological risk posed by ixodid ticks as vectors. Parasitology 2004, 129:37-65.

55. Scharlemann JPW, Johnson PJ, Smith AA, Macdonald DW, Randolph SE: Trends in ixodid tick abundance and distribution in Great Britain. Med Vet Entomol 2008, 22:238-247.

56. Knap N, Durmisi E, Saksida A, Korva M, Petrovec M, Avsic-Zupanc T: Influence of climatic factors on dynamics of questing Ixodes ricinus ticks in Slovenia. Vet Parasitol 2009, 164:275-281.

57. Tagliapietra V, Rosa R, Arnoldi D, Cagnacci F, Capelli G, Montarsi F, Hauffe $H C$, Rizzoli A: Saturation deficit and deer density affect questing activity and local abundance of Ixodes ricinus (Acari, Ixodidae) in Italy. Vet Parasitol 2011, 183:114-124.

58. Tälleklint $L$, Jaenson TG: Relationship between Ixodes ricinus density and prevalence of infection with Borrelia-like spirochetes and density of infected ticks. J Med Entomol 1996, 33:805-811.

59. Güneş T, Kaya S, Poyraz O, Engin A: The prevalence of Borrelia burgdorferi sensu lato in Ixodes ricinus ticks in the Sinop Region of Turkey. Turk J Vet Anim Sci 2007, 31:153-158.

60. Arneberg P, Skorping A, Grenfell B, Read AF: Host densities as determinants of abundance in parasite communities. Proc $R$ Soc Lond $B$ 1998, 265:1283-1289.

61. LoGiudice K, Ostfeld RS, Schmidt KA, Keesing F: The ecology of infectious disease: effects of host diversity and community composition on Lyme disease risk. Proc Natl Acad Sci U S A 2003, 100:567-571.

62. Krasnov BR, Khokhlova IS, Burdelova NV, Mirzoyan NS, Degen AA: Fitness consequences of density-dependent host selection in ectoparasites: testing reproductive patterns predicted by isodar theory in fleas parasitizing rodents. J Anim Ecol 2004, 73:815-820.

63. Peréz-Eid C: Epidemiology of Lyme borreliosis in the commuter belt of Paris. In Report of WHO Workshop on Lyme Borreliosis Diagnosis and Surveillance. Warsaw: WHO; 1995:80-83.

64. Angelov L, Arnaudov D, Rakadjieva TT, Lichev D, Kostova E: Lyme borreliosis in Bulgaria (epidemiologic and epizootologic review). In Report of WHO Workshop on Lyme Borreliosis Diagnosis and Surveillance. Warsaw: WHO; 1995:41-52.

65. Estrada-Peña A, Osacar JJ, Pichon B, Gray JS: Hosts and pathogen detection for immature stages of Ixodes ricinus (Acari: Ixodidae) in North-Central Spain. Exp Appl Acarol 2005, 37:257-268.

66. Juřicová Z, Hubálek Z: Serologic survey of the wild boar (Sus scrofa) for Borrelia burgdorferi sensu lato. Vector Borne Zoonotic Dis 2009, 9:479-482.

67. Landesbetrieb Wald und Holz NRW: Wildschweinbestände mit Zukunft. Detmold: Hermann Bösmann Verlag; 2009.

68. Landesbetrieb Wald und Holz NRW: Fallwildbericht: Auswertung der im Jagdjahr 2008/09 durchgeführten Fallwilduntersuchungen im Land Nordrhein-Westfalen. Bonn: Leppelt Grafik \& Druck GmbH; 2009.

69. Landesbetrieb Wald und Holz NRW: Fallwildbericht: Auswertung der im Jagdjahr 2009/10 durchgeführten Fallwilduntersuchungen im Land Nordrhein Westfalen. Bonn: Carthaus GmbH \& Co.KG; 2010.

70. Ruiz-Fons F, Gilbert L: The role of deer as vehicles to move ticks, Ixodes ricinus, between contrasting habitats. Int J Parasitol 2010, 40:1013-1020.

71. Matuschka FR, Heiler M, Eiffert H, Fischer P, Lotter $H$, Spielman A: Diversionary role of hoofed game in the transmission of Lyme disease spirochetes. AmJTrop Med Hyg 1993, 48:693-699.
72. Rosef O, Paulauskas A, Radzijevskaja J: Prevalence of Borrelia burgdorferi sensu lato and Anaplasma phagocytophilum in questing Ixodes ricinus ticks in relation to the density of wild cervids. Acta Vet Scand 2009, 51:47.

73. Estrada-Peña A, Acevedo P, Ruiz-Fons F, Gortázar C, de la Fuente J: Evidence of the importance of host habitat use in predicting the dilution effect of wild boar for deer exposure to Anaplasma spp. PLoS One 2008, 3:e2999.

74. Pérez D, Kneubühler Y, Rais O, Jouda F, Gern L: Borrelia afzelii ospC genotype diversity in Ixodes ricinus questing ticks and ticks from rodents in two Lyme borreliosis endemic areas: contribution of co-feeding ticks. Ticks Tick Borne Dis 2011, 2:137-142.

75. Gern L, Hu CM, Kocianova E, Vyrostekova V, Rehacek J: Genetic diversity of Borrelia burgdorferi sensu lato isolates obtained from Ixodes ricinus ticks collected in Slovakia. Eur J Epidemiol 1999, 15:665-669.

76. Kurtenbach K, Peacey M, Rijpkema SG, Hoodless AN, Nuttall PA, Randolph SE: Differential transmission of the genospecies of Borrelia burgdorferi sensu lato by game birds and small rodents in England. Appl Environ Microbiol 1998, 64:1169-1174.

77. Vennestrøm J, Egholm H, Jensen PM: Occurrence of multiple infections with different Borrelia burgdorferi genospecies in Danish Ixodes ricinus nymphs. Parasitol Int 2008, 57:32-37.

78. Pichon B, Rogers M, Egan D, Gray J: Blood-meal analysis for the identification of reservoir hosts of tick-borne pathogens in Ireland. Vector Borne Zoonotic Dis 2005, 5:172-180.

79. Kurtenbach K, Sewell HS, Ogden NH, Randolph SE, Nuttall PA: Serum complement sensitivity as a key factor in Lyme disease ecology. Infect Immun 1998, 66:1248-1251.

80. Humair PF, Postic D, Wallich R, Gern L: An avian reservoir (Turdus merula) of the Lyme borreliosis spirochetes. Zentralbl Bakteriol 1998, 287:521-538.

81. Kurtenbach K, Carey D, Hoodless AN, Nuttall PA, Randolph SE: Competence of pheasants as reservoirs for Lyme disease spirochetes. J Med Entomol 1998, 35:77-81.

82. Richter D, Spielman A, Komar N, Matuschka FR: Competence of American robins as reservoir hosts for Lyme disease spirochetes. Emerg Infect Dis 2000, 6:133-138

83. Escudero R, Barral M, Perez A, Vitutia MM, García-Pérez AL, Jiménez S, Sellek RE Anda P: Molecular and pathogenic characterization of Borrelia burgdorferi sensu lato isolates from Spain. J Clin Microbio/ 2000, 38:4026-4033.

84. Younsi H, Postic D, Baranton G, Bouattour A: High prevalence of Borrelia lusitaniae in Ixodes ricinus ticks in Tunisia. Eur J Epidemiol 2001, 17:53-56.

85. Zeidner NS, Núncio MS, Schneider BS, Gern L, Piesman J, Brandão O, Filipe AR: A portuguese isolate of Borrelia lusitaniae induces disease in $\mathrm{C} 3 \mathrm{H} /$ HeN mice. J Med Microbiol 2001, 50:1055-1060.

86. Sarih M, Jouda F, Gern L, Postic D: First isolation of Borrelia burgdorferi sensu lato from Ixodes ricinus ticks in Morocco. Vector Borne Zoonotic Dis 2003, 3:133-139.

87. Núncio MS, Péter O, Alves MJ, Bacellar F, Filipe AR: Isolemento e caracterização de borrélias de Ixodes ricinus L. em Portugal. Rev Portug Doenças Infec 1993, 16:175-179.

88. Postic D, Korenberg E, Gorelova N, Kovalevski W, Bellenger E, Baranton G Borrelia burgdorferi sensu lato in Russia and neighbouring countries: high incidence of mixed isolates. Res Microbiol 1997, 148:691-702.

89. Mizak B, Król J: Analysis of Polish isolates of Borrelia burgdorferi by amplification of rrf (5S)-rrl (23S) intergenic spacer. Bull Vet Inst Pulawy 2000, 44:147-154

90. Richter D, Schlee DB, Matuschka FR: Relapsing fever-like spirochetes infecting European vector tick of Lyme disease agent. Emerg Infect Dis 2003, 9:697-701.

91. Jouda F, Crippa M, Perret JL, Gern L: Distribution and prevalence of Borrelia burgdorferi sensu lato in Ixodes ricinus ticks of canton Ticino (Switzerland). Eur J Epidemiol 2003, 18:907-912.

92. Wilhelmsson P, Fryland L, Börjesson S, Nordgren J, Bergström S, Ernerudh J, Forsberg P, Lindgren PE: Prevalence and diversity of Borrelia species in ticks that have bitten humans in Sweden. J Clin Microbiol 2010, 48:4169-4176.

93. Poupon MA, Lommano E, Humair PF, Douet V, Rais O, Schaad M, Jenni L, Gern L: Prevalence of Borrelia burgdorferi sensu lato in ticks collected from migratory birds in Switzerland. Appl Environ Microbiol 2006 72:976-979

94. Norte AC, Ramos JA, Gern L, Nuncio MS, Lopes-de-Carvalho I: Birds as reservoirs for Borrelia burgdorferi s.l. in Western Europe: circulation of $B$. 
turdi and other genospecies in bird-tick cycles in Portugal. Environ Microbiol 2012. doi:10.1111/j.1462-2920.2012.02834.x. in press.

95. de Carvalho IL, Zeidner N, Ullmann A, Hojgaard A, Amaro F, Ze-Ze L, Alves MJ, de Sousa R, Piesman J, Nuncio MS: Molecular characterization of a new isolate of Borrelia lusitaniae derived from Apodemus sylvaticus in Portugal. Vector Borne Zoonotic Dis 2010, 10:531-534.

96. De Sousa R, Lopes de Carvalho I, Santos AS, Bernardes C, Milhano N, Jesus J, Menezes D, Nuncio MS: Role of the lizard Teira dugesii as a potential host for Ixodes ricinus tick-borne pathogens. Appl Environ Microbiol 2012, 78:3767-3769.

97. Majláthová V, Majláth I, Derdáková M, Vichová B, Pet'ko B: Borrelia lusitaniae and green lizards (Lacerta viridis), Karst Region, Slovakia. Emerg Infect Dis 2006, 12:1895-1901.

98. Amore G, Tomassone L, Grego E, Ragagli C, Bertolotti L, Nebbia P, Rosati S, Mannelli A: Borrelia lusitaniae in immature Ixodes ricinus (Acari: Ixodidae) feeding on common wall lizards in Tuscany, central Italy. J Med Entomol 2007, 44:303-307.

doi:10.1186/1756-3305-5-268

Cite this article as: Schwarz et al:: Abundance of Ixodes ricinus and prevalence of Borrelia burgdorferi s.l. in the nature reserve

Siebengebirge, Germany, in comparison to three former studies from 1978 onwards. Parasites \& Vectors 2012 5:268.

\section{Submit your next manuscript to BioMed Central and take full advantage of:}

- Convenient online submission

- Thorough peer review

- No space constraints or color figure charges

- Immediate publication on acceptance

- Inclusion in PubMed, CAS, Scopus and Google Scholar

- Research which is freely available for redistribution 